\title{
Pelatihan Dan Implementasi Sistem Informasi Penetapan Angka Kredit Guru Pada Dinas Pendidikan Kabupaten Padang Lawas Utara
}

\author{
Siti Aisyah, Amir Mahmud Husein, Mawaddah Harahap \\ Univeristas Prima Indonesia, Jalan Sekip Simpang Sekambing, Medan, Sumatera Utara \\ Email : sitiaisyah@unprimdn.ac.id, amirmahmud@unprimdn.ac.id
}

\begin{abstract}
Abstrak
Jumlah guru PNS tingkat SD dan SMP pada Dinas Pendidikan Kabupaten Padang Lawas Utara pada tahun 2018 sebanyak 1.657. Sudah seharusnya memberikan pelayanan yang mudah dan transparan dengan memanfaatkan teknologi informasi, dalam bentuk Sistem Informasi yang terintegrasi dengan database manajemen kepegawaian BKD Kabupaten Padang Lawas Utara secara penuh. Sistem Informasi digunakan sebagai media yang dapat mempermudah pelayanan pengurusan Daftar Usul Penetapan Angka Kredit (DUPAK) bagi guru secara online kepada Tim Operator dan Tim Penilai. Adapun tahapan yang dilakukan adalah : persiapan dengan tim, pembuatan aplikasi, Observasi dan evaluasi, dan refleksi. Aplikasi memudahkan pihak guru untuk mengusulkan PAK dan DUPAK tanpa harus datang langsung ke lokasi Mitra, sehingga memberikan efesiensi waktu dan biaya. Dapat mempermudah Tim Penilai untuk melakukan tugasnya tanpa terbatas tempat dan waktu.

Katakunci: Daftar Usul Penetapan Angka Kredit(DUPAK), Dinas Pendidikan, Kabupaten Padang Lawas Utara
\end{abstract}

\section{Abstract}

The number of civil servant and elementary school teachers in the North Padang Lawas District Education Office is 1,657. It should provide easy and transparent services using information technology, in the form of applications that are integrated with the management of the BKD Padang Lawas Utara database. As a media that can be used to facilitate the management of the Daftar Usul Penetapan Angka Kredit (DUPAK) for teachers online for the Operators and Assessment Teams. What is being done is: preparation with the team, making the application, observation and evaluation, and reflection. Application that makes it easy for all parties to request PAK and DUPAK without having to come directly to the location of Partners, thus providing time and cost efficiency. Can make it easier for the Assessment Team to do their work without limitation of place and time.

Keywords: Daftar Usul Penetapan Angka Kredit(DUPAK), Dinas Pendidikan, Kabupaten Padang Lawas Utara

\section{A. PENDAHULUAN}

Dinas Pendidikan Kabupaten Padang Lawas Utara merupakan salah satu instansi pemerintahan bergerak dibidang pendidikan yang mengatur semua sistem pendidikan yang ada di Kabupaten Padang Lawas Utara dari PAUD, TK, SD dan SMP. Sebagai salah satu kabupaten baru pemekaran, Kabupaten Padang Lawas Utara Tingkat partisipasi 
sekolah penduduk pada tahun 2014 yang diukur dengan Angka Partisipasi Sekolah (APS) menunjukkan bahwa APS pada kelompok usia sekolah dasar sebesar 99,45 persen, SMP (13-15 tahun) sebesar 86,13 persen, SMA (16-18 tahun) sebesar 75,36 persen. Sedangkan lebih jauh lagi indikator Angka Partisipasi Murni (APM) SD sebesar 98,36 persen, SMP sebesar 72,03 persen, di mana jumlah Sekolah Dasar sebanyak 208 dan tingkat Sekolah Menengah Pertama sebanyak 52 dengan jumlah guru PNS sebanyak 1.657, tingkat SD memiliki guru sebanyak 1.338 dan tingkat SMP sebanyak 319 guru (terlampir).

Setiap guru memiliki jenjang jabatan disebut dengan Jabatan fungsional guru yaitu jabatan fungsional yang mempunyai ruang lingkup, tugas, tanggung jawab, dan wewenang untuk melakukan kegiatan mendidik, mengajar, membimbing, mengarahkan, melatih, menilai, dan mengevaluasi peserta didik pada pendidikan anak usia dini jalur pendidikan formal, pendidikan dasar, dan pendidikan menengah sesuai dengan peraturan perundangundangan yang diduduki oleh Pegawai Negeri Sipil. Untuk jenjang kenaikan pangkat guru, wajib membuat Daftar Usul Penetapan Angka Kredit (DUPAK). DUPAK jabatan guru adalah daftar/kumpulan berkasberkas yang berisi dokumen bukti fisik prestasi kerja yang dicapai oleh guru yang telah diperhitungkan angka kreditnya dalam kurun waktu tertentu, DUPAK sesuai dengan Permenneg PAN dan RB Nomor 16 Tahun 2009, dan Kriteria bukti fisik mengacu Permendiknas Nomor 35 Tahun 2010 tentang Petunjuk Teknis Jabatan Fungsional Guru dan Angka Kredit.

Berdasarkan peraturan Permendiknas No. 35 Tahun 2010, setiap guru diwajibkan mengusulkan DUPAK berdasarkan hasil penilaian kinerja kepada kepala sekolah/madrasah setiap tahun berdasarkan bukti fisik, Perubahan proses pengembangan diri dan kenaikan pangkat dengan pola baru ini menimbulkan keresahan dan kepanikan di kalangan guru, mengingat masih terdapat beberapa orang guru yang belum memahami proses perubahan tersebut secara utuh benar, sehingga tidak sedikit dari guru yang akan naik pangkat menjadi korban oknum guru lainnya yang mencoba memanfaatkan kelemahan guru dengan menawarkan jasa pengurusan kenaikan pangkat, selain itu proses pengurusan DUPAK mulai pendaftaran kurang efektif dikarenakan banyaknya birokrasi yang harus ditempuh dalam mengisi formulir dan membutuhkan waktu yang lama untuk mengetahui status kelengkapan berkas dan hasil penilaian dari Tim Penilai. DUPAK yang sudah lengkap diajukan ke Dinas Pendidikan Kabupaten Padang Lawas Utara untuk selanjutnya akan dinilai oleh tim penilai untuk guru golongan IV/a ke bawah, sedangkan untuk golongan $\mathrm{IV} / \mathrm{b}$ hingga IV/d dinilai oleh tim penilai pusat.

Dengan jumlah guru di Kabupaten Padang Lawas Utara sudah seharusnya Dinas Pendidikan memberikan pelayanan yang mudah dan transparan dengan memanfaatkan teknologi informasi dalam bentuk Sistem Informasi yang terintegrasi secara penuh sebagai media yang dapat digunakan untuk mempermudah pelayanan pengurusan DUPAK bagi guru, selain itu juga dapat mempermudah Tim Penilai untuk melakukan tugasnya tanpa terbatas tempat dan waktu. Penerapan teknologi informasi juga dapat memberikan manfaat dan implementasinya merupakan bagian dari e-Government.

\section{B. METODE}

solusi yang disepakati dengan mitra Dinas Pendidikan Kabupaten Padang Lawas Utara berdasarkan skala prioritas, yaitu:

1. Dalam rangka peningkatan pelayanan di instansi Dinas Pendidikan Kabupaten Padang Lawas Utara khususnya masalah pelayanan Penetapan Angka Kredit (PAK) guru, maka diperlukan solusi yaitu Pihak Fakultas Teknologi dan Ilmu Komputer Universitas Prima Indonesia (FTIK UNPRI) Membangun sistem informasi DUPAK berbasis Online yang dapat diakses oleh guru, tim penilai, staf dan pimpinan Dinas Pendidikan 
Kabupaten Padang Lawas Utara. Skema solusi yang diterapkan dalam bentuk sistem informasi PAK Online ditunjukkan pada gambar 1

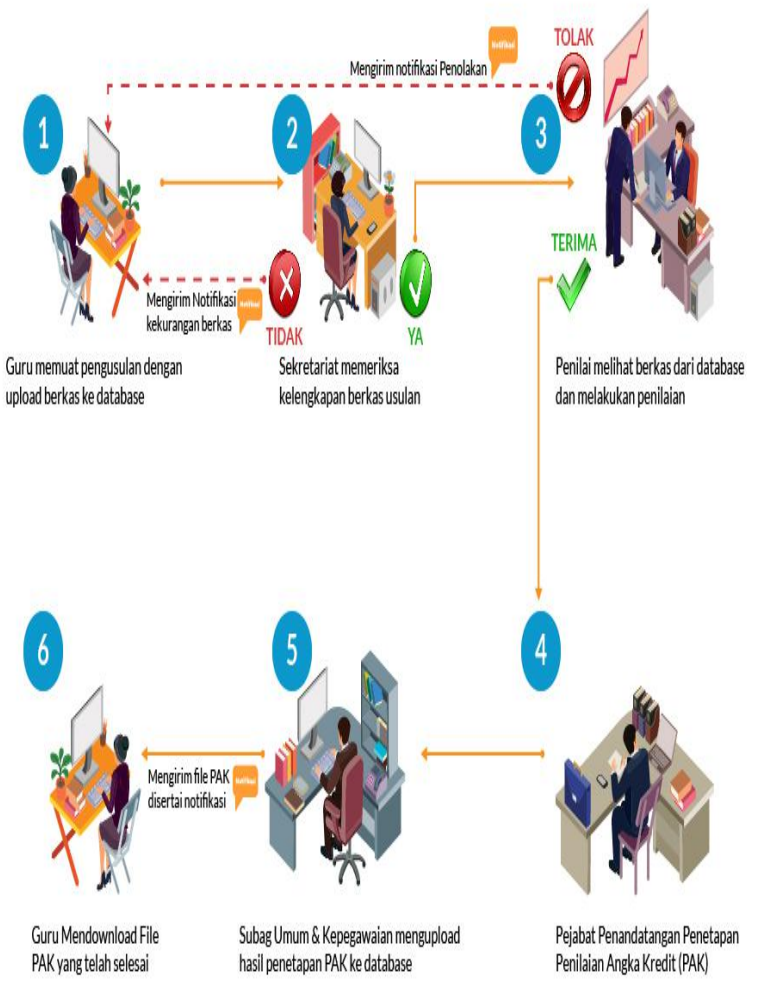

Gambar 1 Skema solusi dalam bentuk sistem informasi PAK Online

Solusi pada mitra yang ditawarkan diharapkan bermanfaat untuk:

a. Memudahkan proses pendaftaran pengusulan Daftar Usul Penetapan Angka Kredit (DUPAK) bagi guru.

b. Memudahkan proses pengiriman berkas guru karena dapat dikirim secara bertahap.

c. Memonitor kekurangan berkas guru sehingga dapat disesuaikan dan dilengkapi dan sistem akan mengirimkan informasi kekurangan berkas.

d. Memudahkan penyampaian informasi antara tim penilai, guru dan Dinas Pendidikan Kabupaten Padang Lawas Utara.

e. Memudahkan proses penilaian perhitungan angka kredit guru. f. Manajemen pemberkasan digital sehingga guru hanya mengirim berkasberkas terbaru, karena berkas sebelumnya sudah tersimpan secara digital.

g. Efisiensi biaya dan waktu sehingga guru tidak perlu bolak-balik ke dinas untuk pengurusan DUPAK karena sudah dapat diakses dari mana saja selama terhubung dengan internet.

2. Untuk peningkatan pemahaman guru tentang sistem informasi, pihak FTIK UNPRI melakukan sosialisasi dan pelatihan penggunaan aplikasi dengan membagi 4 (empat) tahapan, yaitu:

a. Sosialisasi dan Pelatihan sistem kepada tim penilai Dinas Pendidikan.

b. Sosialisasi dan pelatihan sistem kepada pegawai Dinas Pendidikan untuk verifikasi dan validasi berkas

c. Sosialisasi dan pelatihan terhadap guru dengan membagi menjadi 5 (lima) tahapan sesuai jumlah guru.

3. Dalam rangka implementasi Sistem Informasi DUPAK yang dibangun, pihak FTIK UNPRI menyediakan Hosting dan Domain sebagai server penyimpanan data selama Dinas Pendidikan belum memiliki Server.

4. Dalam rangka pemeliharaan dan pengembangan, pihak FTIK UNPRI melakukan pelatihan dan pengembangan baik dari sisi sistem informasi maupun Jaringan kepada TIM yang dibentuk oleh Dinas Pendidikan, sehingga apabila ada masalah atau pertanyaan dari guru mengenai sistem dapat dibantu, selain itu memudahkan pihak FTIK UNPRI untuk berkoordinasi dalam pengembangan jika ada perubahan kebijakan yang belum ada dalam sistem.

Dalam kegiatan pelaksanaan pengabdian masyarakat ini, mengikuti aktivitas pelaksanaan penelitian tindakan yang terdiri dari persiapan, pelaksanaan, observasi, evaluasi dan refleksi. Prosedur kerja untuk 
mendukung metode penyelesaian masalah adalah dengan cara pelaksanaan $30 \%$ teori dan $70 \%$ praktik. Setiap tim penilai, guru, staf Dinas Pendidikan dituntut untuk aktif dan mampu menyelesaikan permasalahanpermasalahan diberikan, Oleh karena waktu pelaksanaan yang hanya 8 bulan, maka diharapkan setelah kegiatan pengabdian ini selesai. Metode pelaksanaan kegiatan pengabdian seperti gambar 1

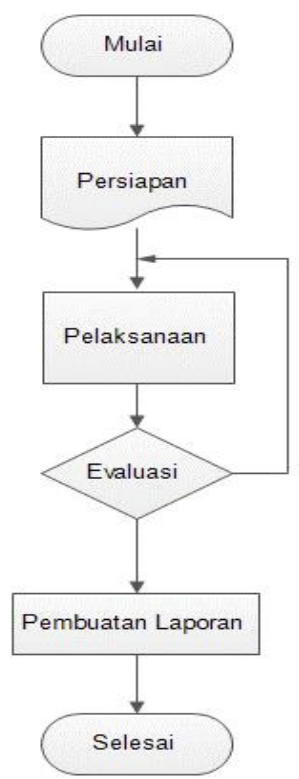

Gambar 1 Flowchart Metode Pelaksanaan

Berikut adalah penjelasan flowchart metode pelaksanaan kegiatan pengabdian masyarakat:

1. Kegiatan Persiapan :

a. Melakukan koordinasi dengan Lembaga Penelitian dan Pengabdian Masyarakat Universitas Prima Indonesia Medan Sumatera Utara.

b. Sosialisasi kegiatan pengabdian kepada Instansi mitra dengan mendatangi Kepala Dinas, Sekretaris dan Bagian Umum dan Kepegawaian Dinas Pendidikan Kabupaten Padang Lawas Utara.

c. Penyusunan program pengabdian berdasarkan hasil analisis situasi.

d. Pengumpulan data untuk keperluan pembuatan Sistem Informasi.

e. Membuat jadwal kegiatan program pengabdian.
2. Pelaksanaan Tindakan:

a. Pembentukan dan pendampingan tim penguji Sistem Informasi dari pihak Dinas Pendidikan Kabupaten Padang Lawas Utara.

b. Sosialisasi dan Pelatihan penggunaan sistem dengan Tim Penilai, Pegawai sebagai operator Dinas Pendidikan.

c. Sosialisasi dan Pelatihan penggunaan sistem dengan guru.

d. Pelatihan dan pendampingan dengan TIM Sistem Informasi Dinas Pendidikan Kabupaten Padang Lawas Utara

\section{Observasi dan Evaluasi}

Kegiatan observasi dilakukan secara langsung oleh tim pelaksana. Observasi berupa hasil implementasi sistem dengan melakukan pengujian secara langsung dengan proses yang berjalan selama ini, Proses evaluasi dilaksanakan untuk mengetahui kekurangan, kendala maupun kesalahan dalam pelaksanaan kegiatan pengabdian.

\section{Refleksi}

Refleksi dilakukan bersama antara tim, staff dan mitra. Hal ini dilakukan untuk mengetahui seluruh proses pelaksanaan kegiatan.

\section{HASIL DAN PEMBAHASAN}

Implementasi Aplikasi Penetapan Angka Kredit (PAK) pada Dinas Pendidikan Kabupaten Padang Lawas Utara

1. Dokumentasi Aplikasi 


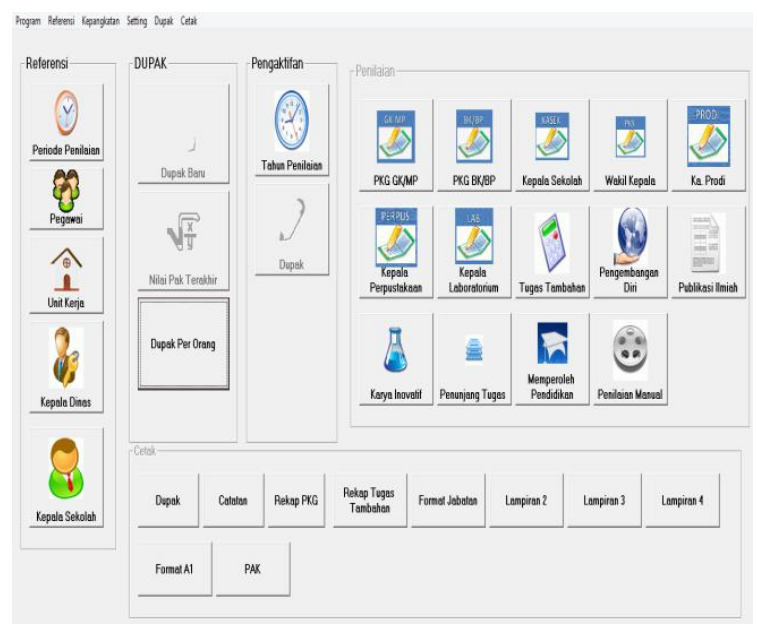

Gambar 2 Menu Utama

Gambar 2 merupakan tampilan menu utama Aplikasi Penetapan Angka Kredit pada Dinas Pendidikan Kabupaten Padang Lawas Utara.

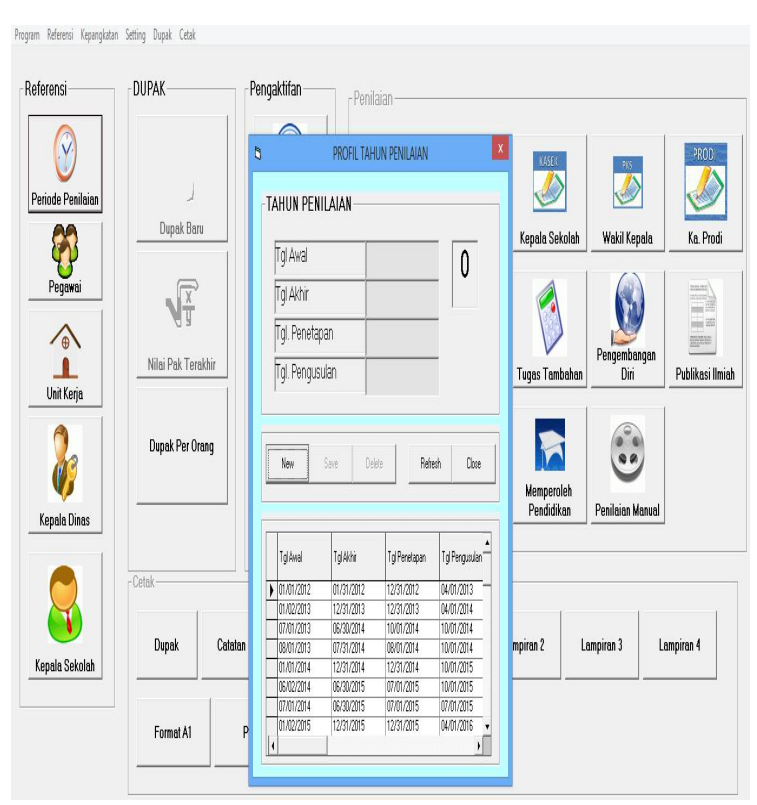

Gambar 3 Tahun Penilaian

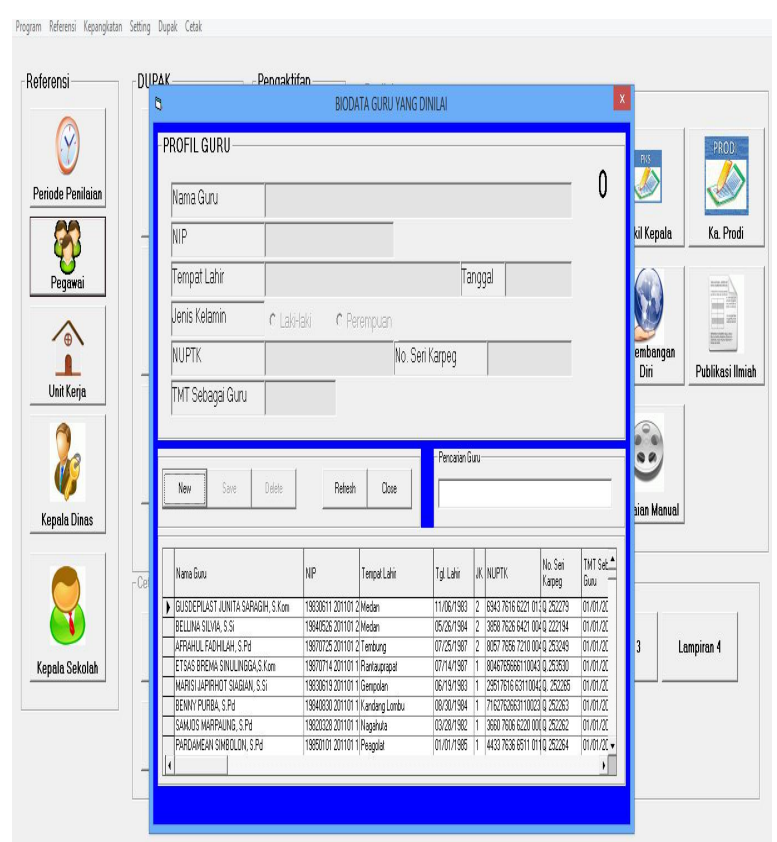

Gambar 4 Profil Guru

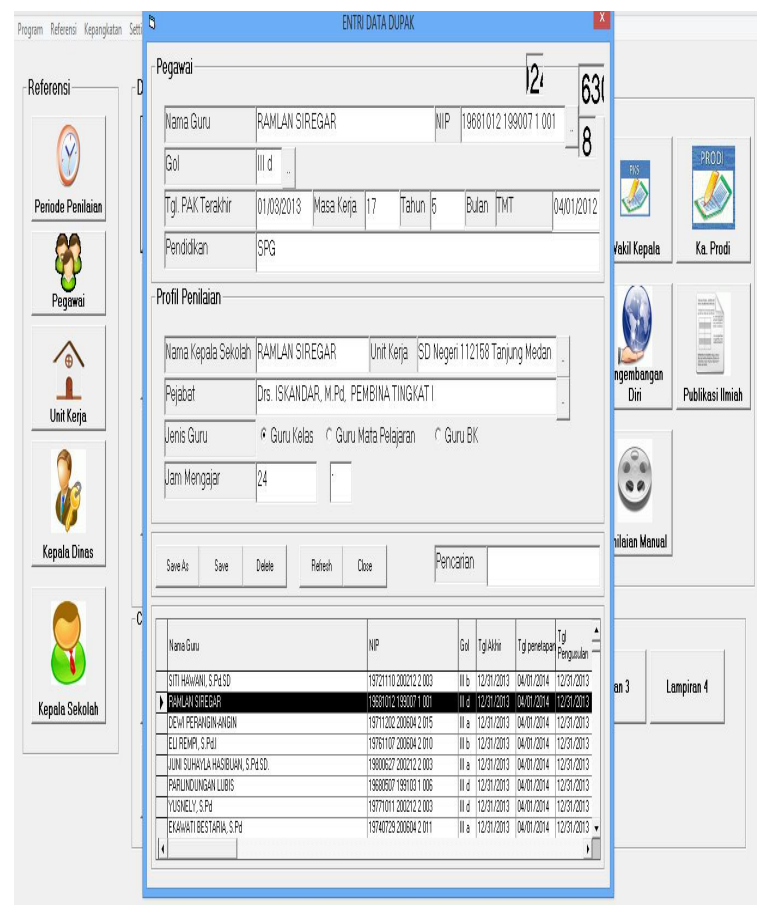

Gambar 5 Pengisian DUPAK 


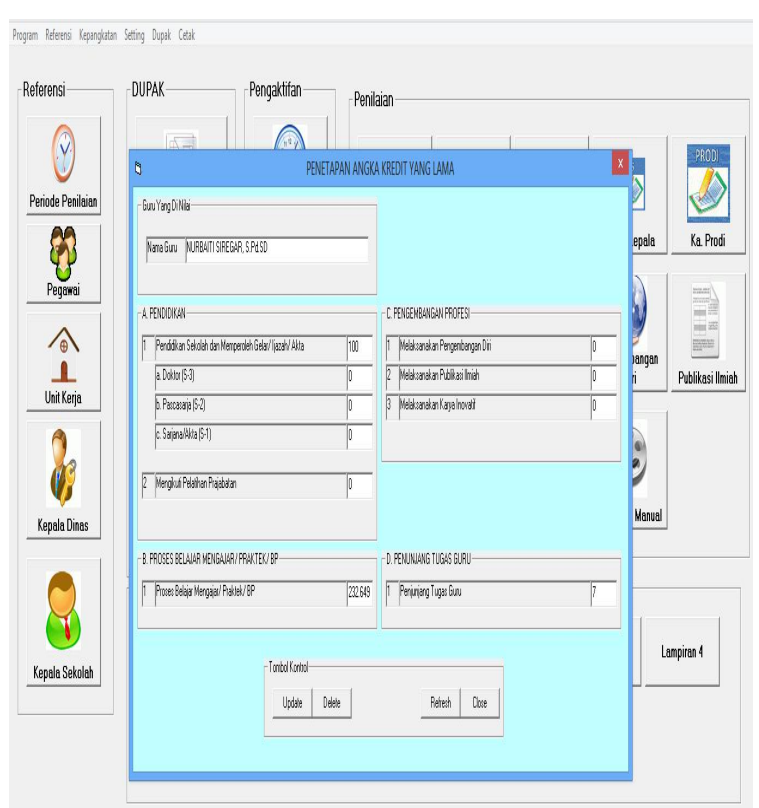

Gambar 6 Pengisian PAK

2. Sosialisasi Penilaian Angka Kredit Pada Dinas Pendidikan Kabupaten Padang Lawas Utara

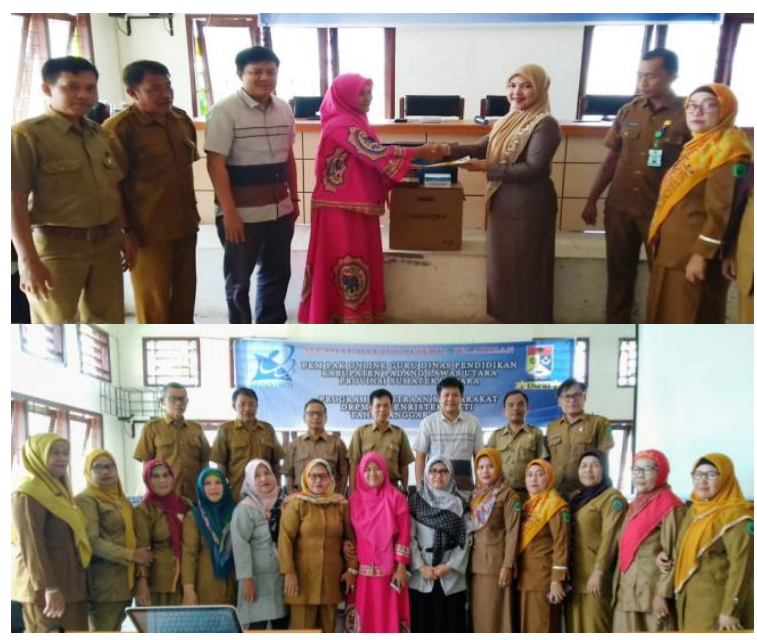

Gambar 7. Serah terima dan sosialisasi

Gambar 7 adalah dokumentasi serah terima aplikasi kepada Kepala Dinas Pendidikan kabupaten padang lawas utara dan Sosialisasi aplikasi Penilaian Angka Kredit secara online kepada perwakilan kepala sekolah Kabupaten Padang Lawas Utara

3. Dokumentasi Pelatihan Tim Operator dan Penilai

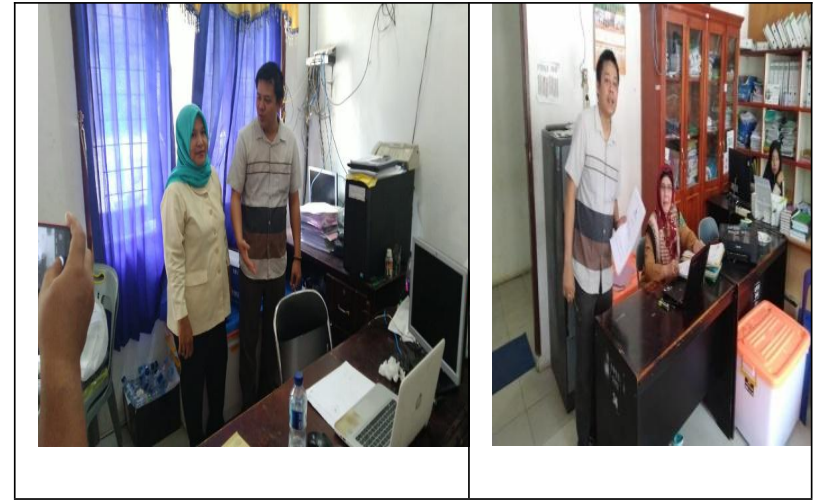

Gambar 7 Dokumentasi Pelatihan Tim Operator

4. Dokumentasi Diskusi dan Evaluasi aplikasi PAK Online
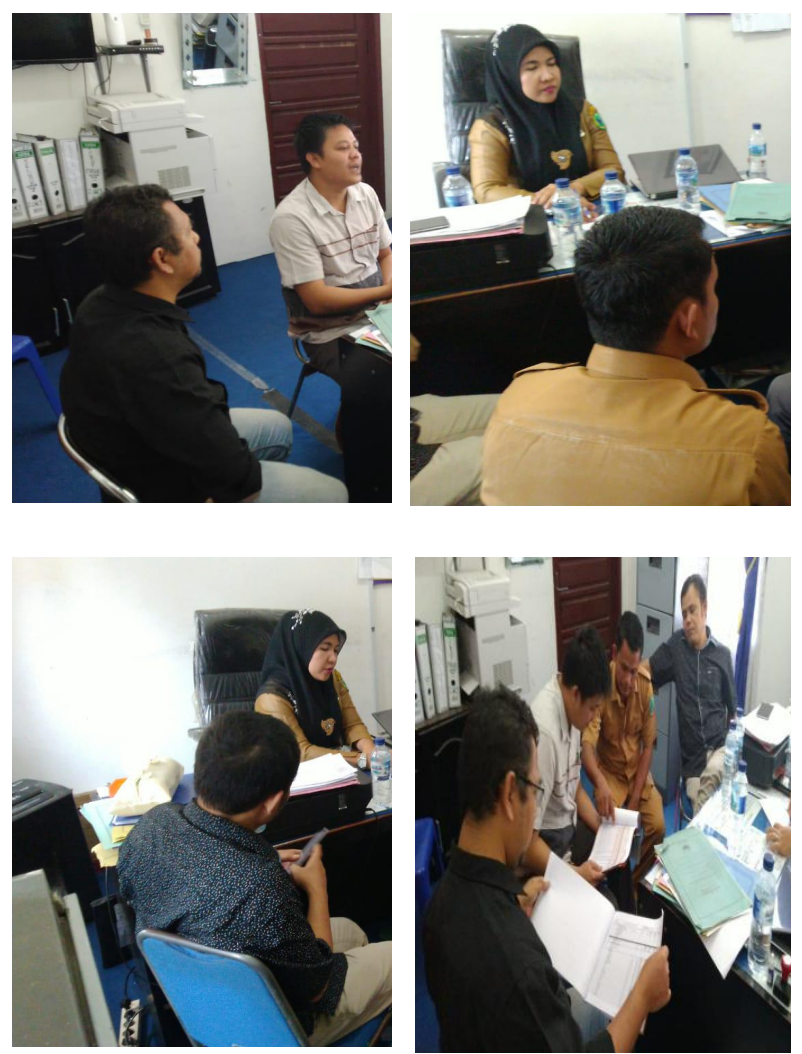

Gambar 8 Dokumentasi Diskusi dan Evaluasi Sistem

\section{KESIMPULAN}

Kesimpulan kegiatan PKM ini dibuat adalah sebagai berikut:

a. Membangun Aplikasi DUPAK Online yang terintegrasi dengan database manajemen kepegawaian BKD Kabupaten Padang Lawas Utara. 
b. Memberikan pelatihan Aplikasi DUPAK

Online kepada Tim Operator dan TIM

Penilai

c. Melakukan evaluasi dan perbaikan

sistem sesuai dengan kondisi dan

peraturan yang berlaku

d. Melakukan diskusi dan evaluasi untuk pengembangan sistem

e. Merencanakan pengembangan sistem berbasis website dan android

\section{E. UCAPAN TERIMA KASIH}

Terima kasih diucapkan kepada :

1. Kemenristekdikti yang telah memberikan bantuan berupa dukungan dana.

2. Universitas Prima Indonesia yang telah memberikan dukungan motivasi dan fasilitas

3. Dinas Pendidikan Kabupaten Padang Lawas Utara yang bersedia sebagai mitra yang bersedia bekerjasama dalam membangun Sistem Informasi Penilaian Angka Kredit (PAK)

\section{DAFTAR PUSTAKA}

Prabowo, Nugroho A, Hidayah, Nur, 2015, Sistem Penetapan Angka Kredit untuk Kenaikan Pangkat Guru di Lingkungan Pemerintah Kota Magelang Berbasis Web, Scientific Journal of Informatics, Vol. 2, No. 2, 155-164, p-ISSN 24077658, e-ISSN 2460-0040.

Peraturan Manteri Pendidikan Nasional Nomor 35 Tahun 2010 tentang Petunjuk Teknis Jabatan Fungsional Guru dan Angka Kredit.

Inpres No.3 tahun 2003 (tentang kebijakan dan Strategi nasional pengembangan eGovernment)

KepmenPAN 63 th 2003 tentang Pedoman Umum Penyelenggaraan Pelayanan Publik

Marshita Yeni 2013, Perancangan Sistem Informasi Usulan Penetapan Angka Kredit Guru Berbasis Web, [Diakses 02 Agustus 2018] dari http:// download. portalgaruda.org /article.php? article $=129164 \&$ val $=1482$

https://palutakab.bps.go.id/ diakses 05 April 
